Int. J. Dev. Biol. 54: 1033-1043 (2010)

doi: $10.1387 / \mathrm{ijdb} .103105 \mathrm{gs}$

\title{
Primitive and definitive erythropoiesis in the yolk sac: a bird's eye view
}

\author{
GUOJUN SHENG* \\ Laboratory for Early Embryogenesis, RIKEN Center for Developmental Biology, Kobe, Hyogo, Japan
}

\begin{abstract}
The yolk sac is the sole niche and source of cells for primitive erythropoiesis from E1 to $E 5$ of chicken development. It is also the main niche and source of cells for early definitive erythropoiesis from E5 to E12. A transition occurs during late embryonic development, after which the bone marrow becomes the major niche and intraembryonically-derived cells the major source. How the yolk sac is involved in these three phases of erythropoiesis is discussed in this review. Prior to the establishment of circulation at E2, specification of primitive erythrocytes is discussed in relation to that of two other cell types formed in the extraembryonic mesoderm, namely the smooth muscle and endothelial cells. Concepts of blood island, hemangioblast and hemogenic endothelium are also discussed. It is concluded that the chick embryo remains a powerful model for studying developmental hematopoiesis and erythropoiesis.
\end{abstract}

KEY WORDS: chicken, primitive erythropoiesis, definitive erythropoiesis, hematopoiesis, yolk sac

\section{Introduction}

Studies on chicken hematopoietic development have been instrumental in the establishment of several key concepts in the field, including B lymphocytes, hematopoietic stem cells, hemangioblasts and hemogenic endothelium. Research focus in recent years has shifted heavily toward genetic and molecular based investigation, leading to a bias against the use of avian models. The wealth of published literature on descriptive and experimental analyses of chicken hematopoiesis, however, is still unsurpassed by any other model organism. The completion of chicken genome (International Chicken Genome Sequencing Consortium, 2004) has made molecular analysis relatively straightforward and genetic analysis possible. In addition to superb spatial and temporal resolution in developmental studies, the chick model serves as an evolutionary link between mammals and lower vertebrates. Here I will provide an embryological overview of chicken extraembryonic hematopoietic development, and focus more detailed discussion on the involvement of the yolk sac in the generation of primitive and definitive red blood cells. Readers interested in other related aspects of chicken hematopoietic development may find relevant details in articles and monographs for general description of hematopoiesis (DieterlenLievre and Le Douarin, 2004; Jaffredo et al., 2003; Le Douarin, 1978; Metcalf and Moore, 1971; Romanoff, 1960), molecular regulation of hematopoiesis (Bollerot et al., 2005; Minko et al.,
2003; Siatskas and Boyd, 2000), hematological description of different blood lineages (Lucas and Jamroz, 1961), early vascular morphogenesis (Drake, 2003; Drake et al., 1998; Drake et al., 2000) and developmental and adult immune systems (Davison et al., 2008).

\section{Yolk sac, amnion, chorion and allantois}

Extraembryonic tissues in developing chick embryo contain the following four components: yolk sac, amnion, chorion and allantois (Fig. 1 A,B). The term "extraembryonic", however, is somewhat a misnomer, as there is no clear anatomical or molecular demarcation to separate the embryonic from the extraembryonic tissues during the first few days of development, and at later stages both are integral components of the developing embryo. This is especially so for the hematopoietic system after the establishment of circulation by the end of embryonic day 2 (E2). Furthermore, the yolk sac, the most prominent component of the extraembryonic tissues, is withdrawn into the abdomen after hatching and is technically embryonic. The allantois, formed near the tail bud at the junction between embryonic and extraembryonic tissues, has contributions from both. Nevertheless, this review will follow the conventional view of these tissues as extraembryonic.

Before formation of the amnion, chorion and allantois, the yolk sac is the only extraembryonic tissue (Fig. 1 C,D). The amnion

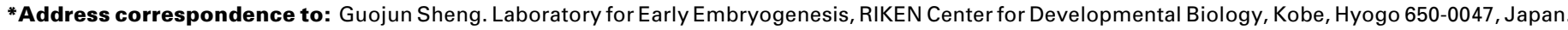
Tel: +81-78-306-3132. Fax: +81-78-306-3146. e-mail: sheng@cdb.riken.jp
} 
and chorion are derived from yolk sac somatopleure. Expansion of extraembryonic coelom separates these two somatopleural tissues from the splanchnopleural tissue, which becomes the later yolk sac. The amnion encloses the developing embryo by the end of E3 (Adamstone, 1948; Lillie, 1919; Romanoff, 1960; Wu et al., 2001). The remainder of the extraembryonic somatopleure becomes the chorion. The allantois grows rapidly from a small out-pocket of hindgut anlage during E3, and from E5 it starts to fuse with the chorion into chorioallantois (DeFouw et al., 1989; Leeson and Leeson, 1963; Lillie, 1919; Melkonian et al., 2002; Romanoff, 1960; Steinmetz, 1930). The formation of chorioallantois involves only the distal wall of the allantois. Its proximal wall starts to fuse with the amnion from E7 (Romanoff, 1960; Steinmetz, 1930) and with the yolk sac during the last few days of embryonic development (Romanoff, 1960). From the perspective of germ layer contribution, the allantois contains endoderm and mesoderm cells, the amnion and chorion contain ectoderm and mesoderm cells, and the yolk sac contains all three germ layers at early stages and mesoderm and endoderm cells after the expansion of the extraembryonic coelom.

\section{Area pellucida, area opaca and area vasculosa}

For the convenience of embryological description and manipulation, early chick blastoderm is separated into area pellucida and
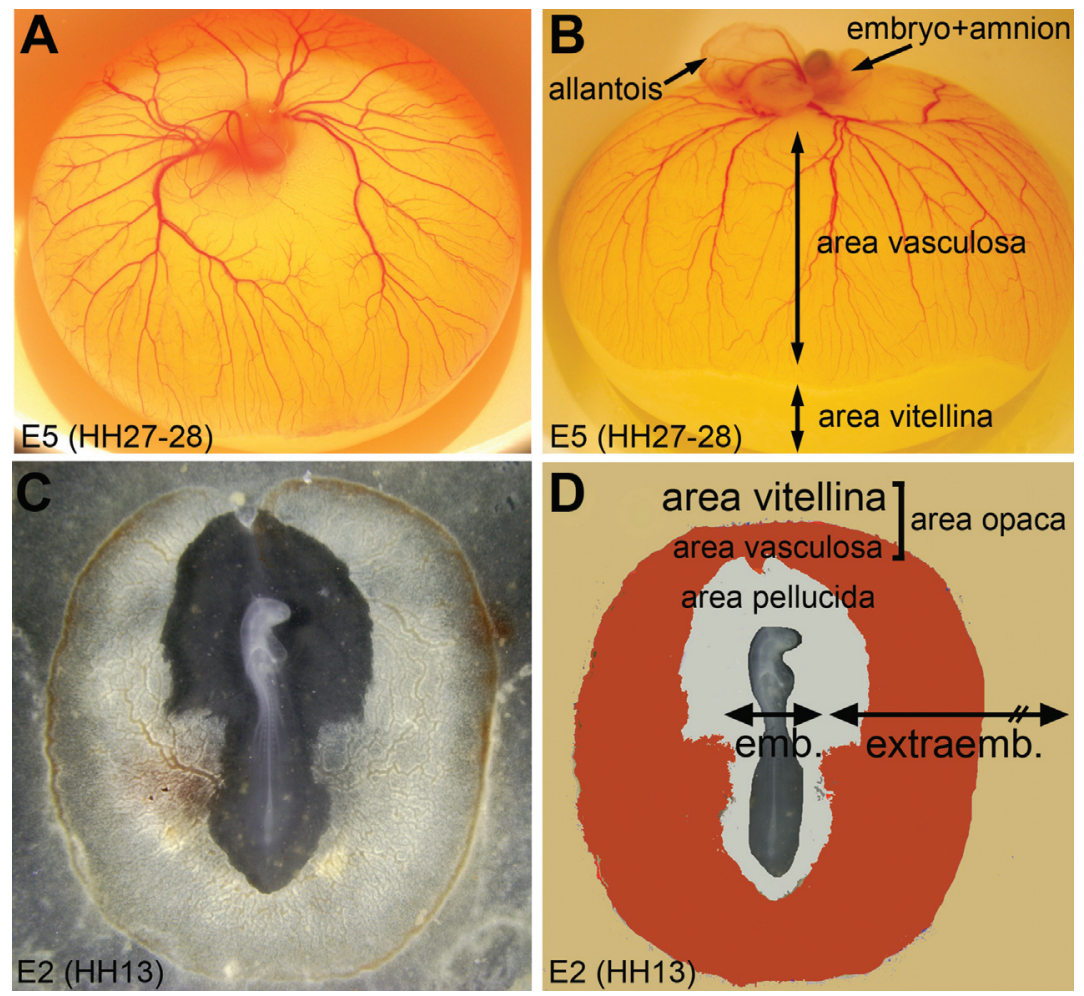

Fig. 1. General organization of chicken extraembryonic tissues. (A,B) $E 5$ embryo. (C,D) E2 embryo. (A) Top view of an E5 embryo before breaking the vitelline membrane and chorion. (B) Top-side view after partial breaking of the vitelline membrane and chorion to reveal the embryo proper (with the amnion) and allantois. At this stage, the area vasculosa has reached the equator and the area vitellina has reached the opposite pole (not seen here). (C) Top view of an E2 (HH13) embryo, showing the area pellucida and area vasculosa. Most of the area vitellina is not included here. (D) Schematic diagram of (C). area opaca based on the opaque appearance of endoderm cells in the outer region with abundant intracellular yolk granules and attached acellular yolk (Bellairs, 1958; Bellairs, 1963; Bellairs, 1964) (Fig. 1 C,D). This does not, however, correspond to the traditional division of intraembryonic and extraembryonic tissues, because a significant part of the area pellucida contributes also to extraembryonic tissues (Fig. 1D). Depending on the extent of area vasculosa, area vitellina and margin of overgrowth (Bellairs, 1963). The margin of overgrowth, located at the extreme peripheral region, contains a special type of ectoderm cells responsible maintaining epiblast tension and for the epiboly process that 1967; New, 1959). The area vitellina is the region of the yolk sac that does not yet contain mesoderm cells. The area vasculosa, derm invasion (Fig. 1 B,D). Medially, the area vasculosa is continuous with vascular regions in the area pellucida. The area asculosa expands laterally to replace the area vitellina (Bellairs, 1963; Romanoff, 1960). When circulation starts at E2 (Fig. 1 C,D), the area vasculosa occupies only a very small part of the entire yolk sac, whereas the margin of overgrowth has already expanded to the equatorial region. By E5 (Fig. 1 A,B), the area vasculosa reaches the equator and the area vitellina has covered most of the yolk. By E15, the area vasculosa covers the entire yolk and the area vitellina disappears. The expansion of the area vitellina and area vasculosa shows noticeable variations in relationship both to each other and to the growth of the embryo proper based on the Hamburger and Hamilton staging criteria (Hamburger and Hamilton, 1992), suggesting a need in the future to establish an independent staging system for the extraembryonic tissues. As yolk sac erythropoiesis takes place exclusively in the mesoderm lineage, only the area vasculosa part of the yolk sac will be discussed in this review. Early yolk sac erythropoiesis occurs in the extraembryonic mesoderm before the expansion of the extraembryonic coelom and the invasion of the allantois, and thus in the context of all three germ layers. Late yolk sac erythropoiesis takes place in splanchnic mesoderm-derived tissues adjacent to the yolk sac endoderm.

\section{Extraembryonic mesoderm and ventral me- soderm}

All mesoderm cells are generated from the primitive streak in the area pellucida (timeline in Figure 4). The most lateral extraembryonic mesoderm cells are derived from early mesoderm cells generated from stage $\mathrm{HH} 2$ onward in the elongating primitive streak. Fates of mesoderm precursors in the primitive streak vary depending on the stages. Generally speaking, posterior part ( $1 / 2$ to $1 / 3)$ of the primitive streak continues to give rise to extraembryonic fated mesoderm from $\mathrm{HH} 2$ to at least HH9 (Murray, 1932; Nakazawa et al., 2006; Nocolet, 1970; Peebles, 1898; Psychoyos and Stern, 1996; Rawles, 1936; Rosenquist, 1966; Rudnick, 1938; 
Sawada and Aoyama, 1999; Schoenwolf et al., 1992; Spratt, 1942; Spratt, 1946; Spratt, 1947; Spratt and Haas, 1965). Relative to more axially located mesoderm lineages (the axial, paraxial, intermediate and lateral plate mesoderm), extraembryonic mesoderm precursors are of the ventralmost fate and populate the lateralmost regions of the developing embryo. The extraembryonic mesoderm covers a wide area and has its own dorsal/ventral and anterior/posterior patterning processes. The chick embryo during first few days of its development takes the shape of a relatively flat sheet (Fig. 2), and the dorsal/ ventral axis of the extraembryonic mesoderm is reflected in the medial/ lateral positional difference relative to the embryo proper. Its anterior/posterior axis is similar to that in the embryo proper and reflects the extent of extraembryonic mesoderm migration from the posterior end of the primitive streak to the anterior-most position rostral to the embryonic forebrain. This aspect has not received much investigation so far, although early work by Sabin provided some descriptions of anterior/posterior positional difference in early phases of primitive hematopoiesis (Sabin, 1920). Within the extraembryonic mesoderm, the axis from the extraembryonic ectoderm to the
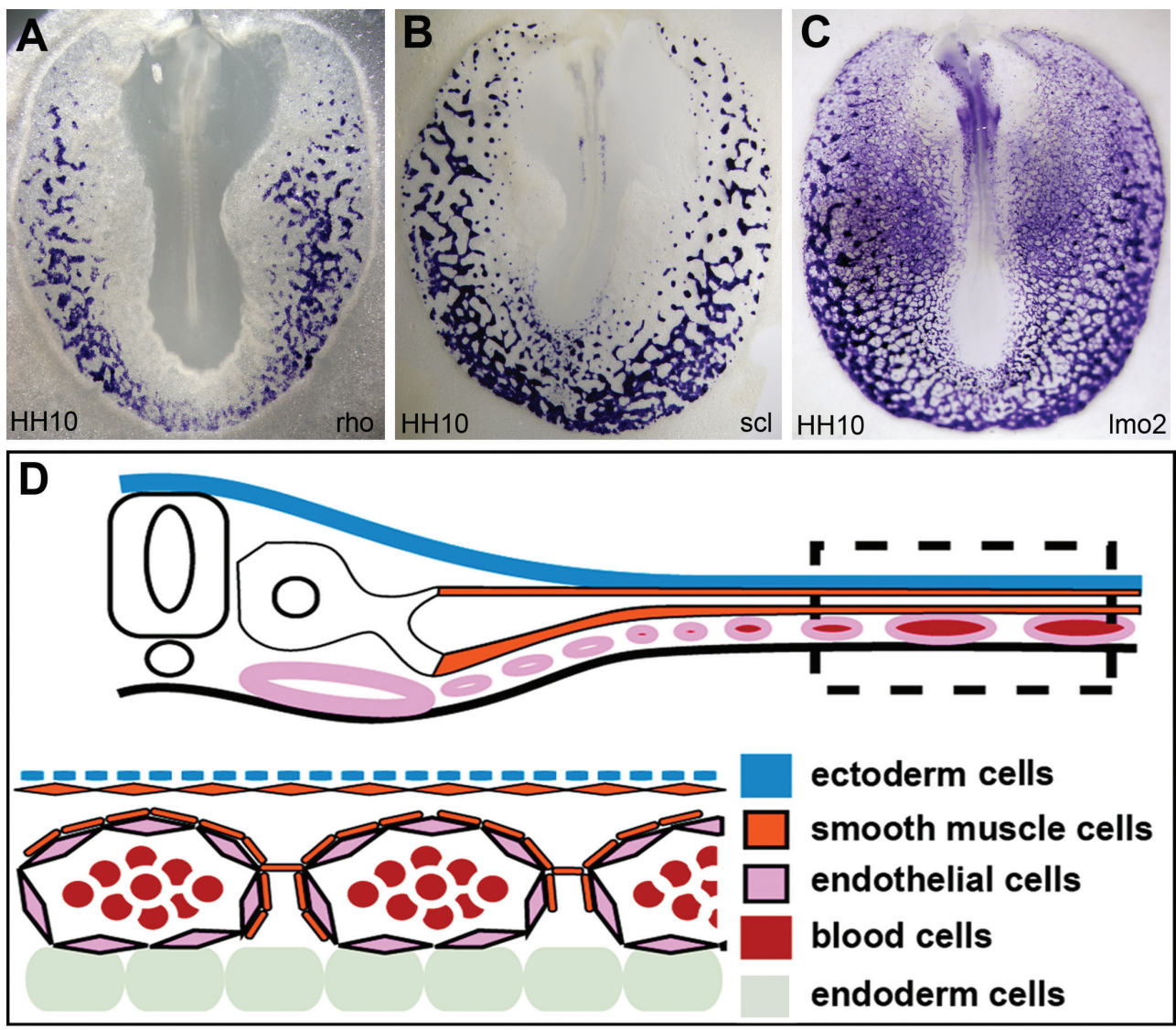

Fig. 2. Primitive erythropoiesis in the yolk sac. (A) rho globin expression at HH10, revealed using a rho intron-specific probe. (B) scl expression at HH10, marking the blood precursors at this stage. (C) Imo2 expression at HH10, marking both the developing vasculature and blood cells. (D) Schematic diagram of an E2 embryo section, showing primitive blood cells in relationship to the ectoderm, endoderm and other extraembryonic mesoderm cell types.

extraembryonic endoderm is sometimes also referred to as dor$\mathrm{sal} / \mathrm{ventral}$. To avoid confusion, mesoderm positional difference along this axis is discussed here with specific reference to the ectoderm, endoderm or coelomic cavity.

\section{Ventral mesoderm lineages}

During and after the migration to populate extraembryonic territories, mesoderm cells differentiate into three main lineages: blood, endothelial and smooth muscle cells (Fig. 2) (Shin et al., 2009). Yolk sac splanchnic mesoderm contains all three lineages (Fig. 2D). Yolk sac somatic mesoderm contains mainly smooth muscle cells that line the extraembryonic ectoderm (Adamstone, 1948; Oppenheim, 1966; Pierce, 1933; Romanoff, 1960; Shin et al., 2009; Wu et al., 2001) (Fig. 2D). Small and infrequent blood islands with differentiated blood and endothelial cells have also been observed in the extraembryonic somatopleure in our analyses (unpublished data) (Alev et al., 2010), suggesting that blood and endothelial lineages do not segregate completely into the splanchnopleure during early extraembryonic mesoderm patterning. Among these three lineages, progenitors for the smooth muscle cells, contributing to both the somatopleure and splanchnopleure, separate first from the other two soon after their ingression through the primitive streak (Shin et al., 2009), followed by the separation of blood and endothelial cells within the blood island cell population (Nakazawa et al., 2006). Sabin reported a similar observation that the cells contributing to exocoelomic walls separate first from the angioblasts (blood island cells) (Sabin, 1917; Sabin, 1920). The splanchnic wall of the extraembryonic coelom is the source of cells for the vascular smooth muscle layer during vasculogenesis, and after formation of the vascular network, vascular smooth muscle layer is in direct contact with the extraembryonic coelomic cavity. This general organization of somatopleural and splanchnopleural tissues in the yolk sac is supported by ultrastructure studies (Kessel and Fabian, 1985; Murphy and Carlson, 1978).

\section{Blood island}

Progenitor cells for blood and endothelial cells form aggregates. This is the earliest morphological sign of differentiation in the extraembryonic mesoderm. Different terms have been used to describe these aggregates, including blood islands, angioblasts and hemangioblasts. Wolff (1764 Theorie von der generation) is generally credited for the earliest description of the blood islands. Initially called "substanzinseln" by Wolff and "Island of Wolff" in English literature, some confusion regarding the connotation of the term "blood island" arose in early $20^{\text {th }}$ century [summarized in 
(Adelmann, 1966; Ruckert, 1906)]. This confusion, still outstanding today, is due to three main observations already apparent to embryologists a century ago (Ruckert, 1906): 1) prior to circulation, aggregates can be observed in the area vasculosa that are associated with both vasculogenesis and hematopoiesis; 2) aggregates can be observed both before and after the appearance of vascular endothelial cells; and 3) aggregates observed before the appearance of vascular endothelial cells are associated more with the territory of vasculogenesis than with that of hematopoiesis. These seemingly contradictory observations, although not so with current knowledge, led Sabin to call early blood islands prior to the appearance of vascular endothelial cells as angioblasts and later blood islands inside the vasculature as true blood islands (Sabin, 1920). Early blood islands, Sabin's angioblasts, were referred to as hemangioblasts by Murray (Murray, 1932). Each hemangioblast, capable of generating both blood and endothelial cells but not necessarily giving rise to both, was defined by Murray as one blood island aggregate, containing many cells. This definition is different from the current use of hemangioblast as a single cell capable of generating blood and endothelial cells after division(s) (Choi et al., 1998; Huber et al., 2004; Park et al., 2005; Ueno and Weissman, 2006; Vogeli etal., 2006). Angioblasts of Sabin are not often used in current literature and hemangioblasts of Murray currently have a strong connotation of cell differentiation potentials. This review uses the term blood island(s) to describe the aggregate(s) prior to the formation of vasculature, blood cell aggregate(s) to describe Sabin's blood island(s) inside vessel lumen prior to their separation into individual blood cells, and hemangioblasts, in the sense that each is a single cell, only when referring to the bi-potential nature of these early blood island cells.

Larger blood islands, constituting more cells in a given blood island and with more cells percentagewise contributing to the blood lineage, are present in more lateral regions of the area vasculosa. Progressively smaller blood islands are observed medially (Fig. 2). Blood islands formed in extraembryonic part of the area pellucida and in the intraembryonic lateral plate are very small, containing a few cells and only giving rise to endothelial cells. Thus during primitive erythropoiesis, the area vasculosa can be divided into hemogenic and non-hemogenic regions. Blood islands in the hemogenic region generate both primitive blood and endothelial cells and those in the non-hemogenic region generate only endothelial cells (Nakazawa et al., 2006; Ruckert, 1906; Sabin, 1920). The transition between hemogenic and non-hemogenic regions is gradual and not clearly demarcated morphologically or molecularly. This is also true for the transition between the nonhemogenic extraembryonic region and the intraembryonic lateral plate vessels. During primitive hematopoiesis, erythrocyte formation has always been observed in association with endothelial cell formation in our studies, whereas endothelial cells often form from small blood islands with no accompanying erythropoiesis.

\section{Primitive erythrocyte differentiation}

Blood islands first appear at around stage $\mathrm{HH} 6$ in a $\mathrm{U}$ or $\mathrm{V}$ shaped area marking the posterior and lateral extents of extraembryonic mesoderm expansion. The earliest erythropoietic differentiation marked by hemoglobin gene expression occurs at stage HH7 (0-1 somite stage) (Nakazawa et al., 2006). Molecularly, however, extraembryonic mesoderm differentiation starts as soon as they are generated from the posterior primitive streak. The earliest appearance of extraembryonic coelom varies from $\mathrm{HH} 6$ to $\mathrm{HH}$. Hemoglobin expression appears initially only in the most
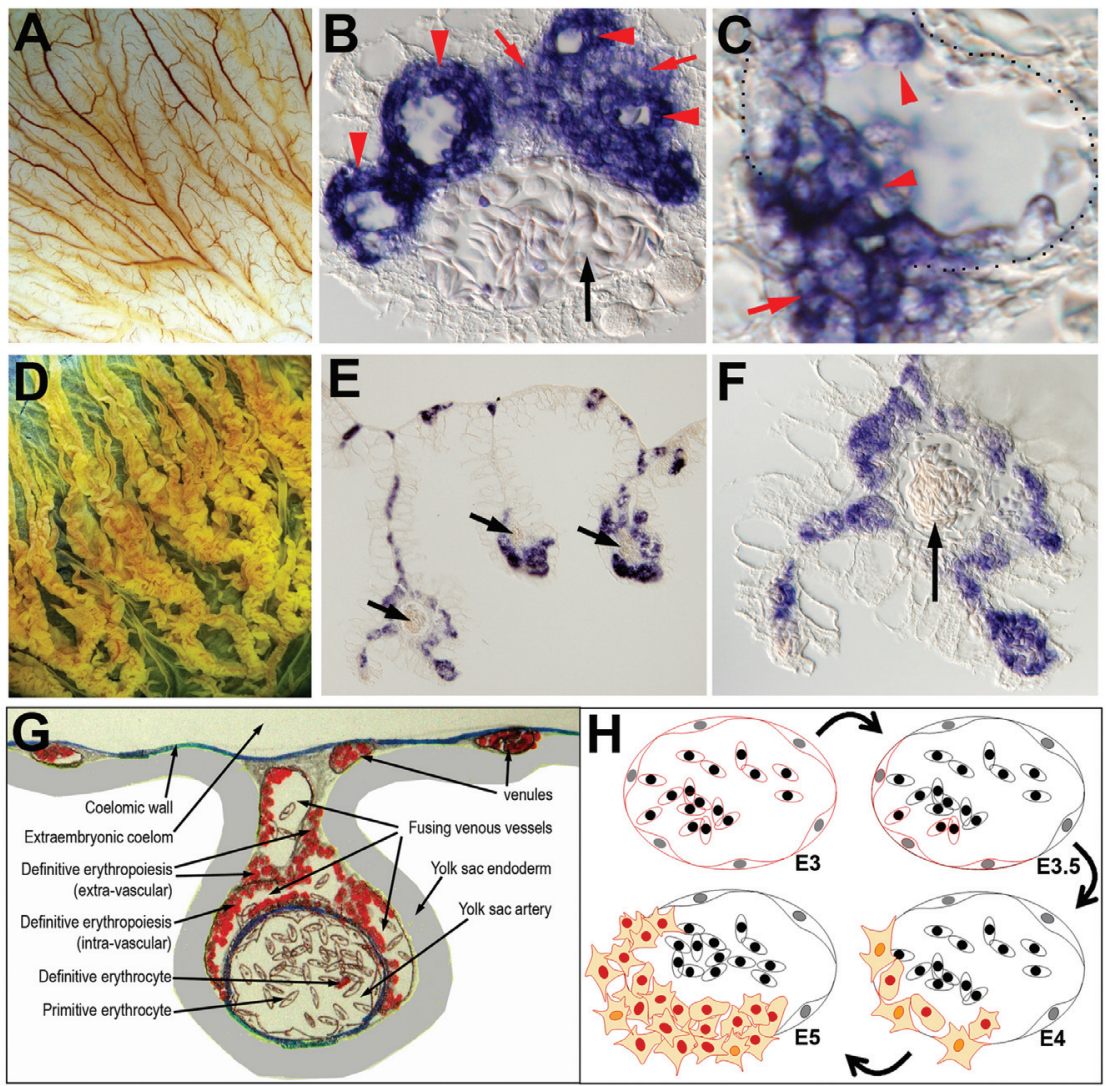

Fig. 3. Definitive erythropoiesis in the yolk sac. (A) View of a region of $E 5$ yolk sac from the ectoderm side. (B,C) Section of E5 (B) or E4 (C) yolk sac after in situ using a betaA globin-specific locked nucleic acid (LNA)-based probe, showing active erythropoiesis in association with venous vessels. Black arrow: artery. Red arrows: extra-vascular clusters. Red arrowheads: intra-vascular clusters. (D) View of a region of E10 yolk sac from the endoderm side. (E,F) Section of E10 yolk sac after in situ using the betaA LNA probe, showing active erythropoiesis in association with venous vessels. More intra-vascular clusters are seen at this stage. Arrows: artery. (G) Schematic drawing of E5 yolk sac section. (H) A model for how early definitive erythrocytes are generated in the yolk sac. Two possible sources, as discussed in the text, are combined here in this model. At E3, both primitive erythrocytes and vascular endothelial cells retain some hematopoietic potential. At E3.5, this potential is lost in most primitive erythrocytes and endothelial cells, but is retained or enhanced in a small percentage of both cell types. At E4, dedifferentiation of these hematopoietic cells occurs, leading to formation of hematopoietic cell clusters, and at slightly later stage (E4.5-5), of erythropoietic clusters. Some of these hematopoietic cells may give rise to other blood lineages or stem/progenitor cells (marked with orange nucleus in E4 and E5). 
peripheral blood islands, reflecting progressive phases of differentiation (Fig. $2 \mathrm{~A}-\mathrm{C}$ ). Although it is considered that more centrally located cells in a given blood island differentiate into blood whereas outer cells into endothelial cells, details of morphological differentiation at the cellular level are so far unclear. Within a given blood island, hemoglobin gene expression precedes morphological distinction between blood and endothelial cells (Nakazawa et al., 2006). Although cell divisions occur in undifferentiated extraembryonic mesoderm cells and subsequently in blood island cells and later differentiated mesoderm lineages, the cell fate choice between blood and endothelial lineages among blood island cells is made largely in the context of cell population, instead of progenies of cell divisions (Weng et al., 2007), suggesting that hemangioblasts as currently defined do not play a major role during primitive blood and vascular formation. After the differentiation of blood island cells into blood and endothelial lineages, endothelial cells from individual blood islands anastomose to form primary vascular plexus. By stage $\mathrm{HH} 10$ (10 somites), before the initiation of circulation at stage $\mathrm{HH} 12-13$, a well-formed vascular network is recognizable in the area vasculosa (Fig. 1C). In the hemogenic region of the area vasculosa, blood cells at stage $\mathrm{HH} 10$ are still observed as clusters, the blood islands by Sabin's definition. Individual blood cells have smoother surface than at earlier stages, yet they still adhere to each other and to the endothelial wall. By stage $\mathrm{HH} 12-13$, when the circulation starts, most blood cells in well established vascular channels have lost contacts to each other and to the endothelium, and become free circulating cells (Fig. 4). More medially located blood islands at this stage still have an "immature" morphology and are not connected to the circulation, reflecting the fact that they are generated later than laterally located ones.

\section{Primitive vs. definitive erythrocytes}

The shift from primitive to definitive erythropoiesis is considered to start at E5 of chicken development. This is based on studies of dynamic changes in hemoglobin composition and erythrocyte morphology in circulating blood. Physiological and molecular mechanisms regulating the timing of this shift are not clear, although change in tissue oxygen levels has been hypothesized as one possible cause (Baumann and Meuer, 1992; Baumann et al., 1983). Since the first report of partial beta globin peptide sequences from normal and sickle human blood cells (Ingram, 1956), efforts were made throughout the sixties and seventies to understand developmental changes in chicken hemoglobin heterogeneity at the protein level (Beaupain etal., 1979; Brown and Ingram, 1974; Bruns and Ingram, 1973; Fraser, 1961; Hashimoto and Wilt, 1966; Manwell et al., 1966; Manwell et al., 1963; Saha, 1964; Saha and Ghosh, 1965; Shimizu, 1972; Simons, 1966; van der Helm and Huisman, 1958; Wilt, 1962; Wilt, 1967). This was followed by the elucidation of chicken hemoglobin genes and genomic organization in the early eighties (Dodgson and Engel, 1983; Dodgson et al., 1981; Dodgson et al., 1983; Dodgson etal., 1979; Dolan et al., 1983; Dolan et al., 1981; Engel and Dodgson, 1980; Engel et al., 1983; Reitman et al., 1993; Villeponteau et al., 1982; Villeponteau and Martinson, 1981) and of developmental changes in hemoglobin transcript profiles in the ninties (Mason et al., 1995; Minie et al., 1992). These studies, together with more recent genomic analysis, can be summarized as follows. There are seven hemoglobin genes in chickens, three of alpha type (pi-alphaD-alphaA) and four of beta type (rhobetaH-betaA-epsilon) in alpha and beta loci, respectively. Both chicken alpha and beta loci are orthologous to eutherian (true mammals) counterparts (Patel et al., 2008). pi is orthologous to human zeta/pseudo-zeta, alphaD to human mu (also called pseudo-alpha2 or alphaD) and alphaA to human pseudo-alpha1/ alpha2/alpha1/theta. Individual beta hemoglobin genes in chickens and mammals arose by independent duplications and do not form orthologous groups, although their ancestral beta genes before duplication are considered orthologous (Alev et al., 2009; Cooper et al., 2006; Goh et al., 2005; Patel et al., 2008). Primitive erythrocytes in chickens have high pi, rho and epsilon hemoglobin proteins, and definitive erythrocytes have high alphaD, alphaA and betaA. All three alpha globins, however, are present in both primitive and definitive erythrocytes. betaA, in addition to being the major beta globin in definitive erythrocytes, is also weakly present in primitive erythrocytes (Alev et al., 2008). betaH is not detected in primitive erythrocytes and is very low in definitive erythrocytes (Alev et al., 2008; Mason et al., 1995). Analyses on developmental changes of hemoglobin heterogeneity suggest that definitive erythrocytes appear in circulation at E5 and start to constitute the majority of circulating erythrocytes by the end of E7 (Fig. 4). Changes in hemoglobin subtypes have so far only been analyzed with relatively large numbers of blood cells. It is therefore unclear whether changes in hemoglobin transcript and protein heterogeneity can occur at single cell level, either in differentiated erythrocytes or in erythropoietic cells of either lineage.

Both primitive and definitive erythrocytes are nucleated. Mature primitive and definitive erythrocytes have distinct oval shapes measuring on average 8 by 12.7 microns for the former and 7 by 10.3 microns for the latter (Romanoff, 1960). Both lineages progress through several maturation stages, from the most immature megaloblast/hemocytoblast, through proerythroblast, basophilic erythroblast, polychromatophilic erythroblast and reticulocyte, to the final mature erythrocyte (Bruns and Ingram, 1973; Dantschakoff, 1908; Dawson, 1936; Edmonds, 1966; Forkner, 1929; Lemez, 1964; Lucas and Jamroz, 1961; Romanoff, 1960; Small and Davies, 1972; Sugiyama, 1926). These distinctions have been made based on a number of criteria, including general cell and nuclear morphology, histological staining, ratio of nuclei and cell sizes and intracellular organelle and microtubule abundance and distribution. They are all referred to here as erythrocytes based on the fact that even the most immature megalobalsts/ hemocytoblasts have initiated hemoglobin expression. These studies on erythrocyte morphological changes revealed a similar picture to that derived from hemoglobin heterogeneity studies. Definitive lineage cells appear in circulation at E5 and overtake primitive lineage cells percentage-wise by the end of E7. Morphological studies also showed that by the time circulation starts at E2, primitive erythrocytes are still at the "proerythroblast" stage with large and round shape. By the end of E3, oval morphology of polychromatophilic erythroblasts takes over, which last until E6, when they develop first into reticulocytes and finally into mature erythrocytes at the beginning of E9 with a complete loss of cytoplasmic ribosomes. Therefore, by the time definitive lineage appears in circulation in the middle of E5 and takes over as the major lineage by the end of $E 7$, the primitive erythrocytes have not completed its maturation process (Fig. 4). Maturation of definitive 
erythrocytes follows similar progression of stages to that of the primitive lineage, with a notable difference in that the definitive lineage cells do not mature synchronously, due to the fact that new definitive cells are continuously being generated as the embryo grows.

\section{Transition from primitive to definitive wave}

Before definitive erythrocytes enter circulation in the middle of $\mathrm{E} 5$, their progenitor cells have been reported to be associated with venous vessels in the yolk sac from the beginning of E4 (Dantschakoff, 1908; Dantschakoff, 1909; Sabin, 1917). This observation is supported by our recent molecular studies (Nagai and Sheng, 2008). Chick/quail and chick/chick chimera studies (Beaupain etal., 1979; Dieterlen-Lievre, 1975; Dieterlen-Lievre et al., 1976; Lassila et al., 1978; Lassila et al., 1982; Martin et al., 1978) and chick/chick parabiotic studies (Metcalf and Moore, 1971; Moore and Owen, 1965; Moore and Owen, 1967) indicated that, at least during the first few days of definitive erythrocyte generation, the source of cells is mainly yolk sac-derived. At about the same time, if not earlier, intraembryonic hematopoietic cells have been observed in association with the dorsal aorta (DieterlenLievre and Martin, 1981; Jaffredo et al., 2003; Jaffredo et al., 2005; Jaffredo et al., 2000; Jaffredo et al., 1998; Jordan, 1916; Nagai and Sheng, 2008; Olah et al., 1988; Pardanaud et al., 1996). A number of questions can be asked, for instance, about whether dorsal aorta-derived hematopoietic cells undergo definitive erythropoiesis either in circulation or in the yolk sac niche; whether yolk sac-derived hematopoietic cells can find their way to the dorsal aorta; and what is the exact type of cells from the yolk sac that contribute to early definitive erythropoiesis. Chimera studies suggested that even at E5-6, though making minor contributions, intraembryonically-derived cells can generate definitive erythrocytes. Dorsal aorta-derived hematopoietic cells, currently considered to be the only intraembryonic hematopoietic source, may be involved in this process. Our molecular analyses with hematopoietic markers support the notion that hematopoietic cells associated with dorsal aorta are derived from dorsal aorta endothelium (Nagai and Sheng, 2008). This is in agreement with data from cell labeling and EM analyses (Jaffredo et al., 1998). Erythropoiesis, however, is not observed at this early period in either intra-vascular or peri-vascular hematopoietic cells associated with the dorsal aorta (Geerts et al., 1993) (H. Nagai and G. Sheng, unpublished data). Our observations also suggest that during this period, most yolk sac vasculature-associated hematopoietic cells undergo definitive erythropoiesis in situ (Nagai and Sheng, 2008). Dantschakoff distinguished two hematopoietic populations in the yolk sac, the intra-vascular erythropoietic cells and extra-vascular leucopoietic cells (Dantschakoff, 1908; Dantschakoff, 1909). Our observations, however, suggest that at least for erythropoiesis, it can occur both intra- and extra-vascularly (Nagai and Sheng, 2008) (Fig. 3 A-C,G,H). This is supported by a recent EM study (Niimi et al., 2008).

\section{Sources of early definitive erythrocytes}

The source of yolk sac erythropoietic cells is not clearly resolved. As mentioned above, dorsal aorta-derived cells have been suggested to be able to take up the yolk sac niche and undergo erythropoiesis (Beaupain et al., 1979; Dieterlen-Lievre, 1975; Lassila et al., 1978; Lassila et al., 1982; Martin et al., 1978). This in principle may happen, but currently with no strong evidence either for or against it. Judging from the relative timing and scales of hematopoietic cell generation in the yolk sac and dorsal aorta, it seems reasonable to assume that yolk sac erythropoietic cells during early definitive erythropoiesis are primarily yolk sacderived. It is another matter, however, to pinpoint which yolk sac cell lineage(s) is involved in early definitive erythropoiesis. Circulating hematopoietic stem cells in E2 and E3, generated from the primitive wave, could be one possible source, although histological and EM studies argue against such a scenario (Bruns and Ingram, 1973; Dantschakoff, 1908; Dawson, 1936; Edmonds, 1966; Lemez, 1964; Lucas and Jamroz, 1961; Romanoff, 1960; Small and Davies, 1972; Sugiyama, 1926). Cells with hematopoietic stem cell potential, residing outside the vasculature after the initiation of circulation at E2, have also been suggested as a possible source for definitive erythrocytes (Dardick and Setterfield, 1978). Our analyses on mitotic activities and timing of the appearance of definitive hematopoietic and erythropoietic clusters in the yolk sac, however, argue against such a stem cell-based hypothesis, at least during the early stages of definitive erythropoiesis.

This leaves two types of yolk sac-derived cells as possible main sources, the vascular endothelial cells and primitive erythrocytes (Fig. $3 \mathrm{H}$ ). Dantschakoff suggested the venous endothelium as a likely source for definitive erythropoietic cells (Dantschakoff, 1908; Dantschakoff, 1909). This hypothesis is supported by our molecular marker study (Nagai and Sheng, 2008) (Fig. 3 A-C,G). From E2 to E5, yolk sac vasculature undergoes at least two phases of remodeling. Hemodynamic changes initiated by heart pulsation remodels early vascular plexus into arterial and venous trees between E2 and E3, followed by the remodeling from two-dimensional apposing arterial/venous trees to a three-dimensional paired arterial/venous network between E3 and E5 (Eichmann et al., 2005; Gonzalez-Crussi, 1971; le Noble et al., 2004; Nagai and Sheng, 2008; Van Mierop and Bertuch, 1967) (Fig. 4). This second remodeling phase happens in the context of the sinking of major arterial vessels into the yolk, together with associated yolk sac endoderm (Fig. 3G). Smaller venous vessels fuse and come to lie above sunken arteries, and form main paired venous vessel for each artery. Yolk sac definitive erythropoiesis is initiated during this second phase of yolk sac vascular remodeling (Nagai and Sheng, 2008). Hematopoietic foci are observed in venous vessels adjacent to large arteries at E3.5-4, with globin positive definitive erythropoietic cells appearing at E4-4.5 and entering the circulation at E4.5-5. Early definitive erythropoiesis in the yolk sac takes place both intra-vascularly and extra-vascularly in association with remodeling venous vessels adjacent to major arteries and in association with smaller vessels (Fig. 3 B,C). These observations suggest that yolk sac endothelial cells can give rise to erythropoietic cells, either by dedifferentiation first into a hemangioblast type cells or by direct transdifferentiation (Fig. 3H). Such a hypothesis, that hematopoietic cells can be generated from morphologically endothelial shaped cells, is in a sense in agreement with the recent finding of direct generation of hematopoietic cells from the endothelium of dorsal aorta (Bertrand et al., 2010; Boisset et al., 2010; Kissa and Herbomel, 2010). Dantschakoff went one step further and commented that all early vascular endothelial cells possess hemato- 
poietic potency, which is exhibited or restricted differentially in different locations (Dantschakoff, 1909).

The other possibility, that primitive erythrocytes may dedifferentiate into definitive erythrocytes, was also mentioned by Dantschakoff (Dantschakoff, 1908) and others (Lemez, 1964; Romanoff, 1960; Sugiyama, 1926) (Fig. 3H). Our analyses indicate that by the end of E3, circulating primitive erythrocytes still retain prominent hematopoietic marker expression (Nagai and Sheng, 2008). These cells are in the process of primitive erythrocyte maturation as discussed earlier, and exhibit primitive erythrocyte hemoglobin profile. During the period of $\mathrm{E} 4$, hematopoietic markers are rapidly downregulated in circulating primitive erythrocytes, and definitive hematopoietic/erythropoietic clusters appear in the yolk sac venous vessels and small capillary vessels (Nagai and Sheng, 2008). Interestingly, it is also during this period that most primitive erythrocytes have been reported to undergo the last mitotic division among on average six divisions from the earliest megaloblast/hemocytobalst stage, and enter post-mitotic stage (Campbell et al., 1971; Hagopian and Ingram, 1971; Weintraub et al., 1971) (Fig. 4). It may therefore be interesting to test in future experiments whether at least part of definitive clusters is formed by the dedifferentiation of primitive erythrocytes which do not enter the post-mitotic phase (Fig. 3H). Although currently without direct evidence in the context of chicken yolk sac definitive erythropoiesis, similar hypotheses with regard to differentiation plasticity and potentials have been proposed in other systems (Dzierzak, 2002; Graf, 2002; Kingsley et al., 2006; McNagny and Graf, 2003; Orkin and Zon, 2002; Prindull and Fibach, 2007).

\section{Late definitive erythropoiesis}

The picture becomes more complex as embryonic development proceeds. Chimera studies suggest that contribution from intraembryonically-derived definitive erythrocytes, at least by origin, gradually increases, and by E12-13 surpasses the contribution from extraembryonically-derived cells. The major embryonic erythropoietic niche, the bone marrow, has just started active generation of definitive erythrocytes by this time (Dantschakoff, 1909; Metcalf and Moore, 1971). It is possible that some intraebmryonically-derived hematopoietic cells find their erythropoietic niche during mid-incubation period in the yolk sac (Beaupain et al., 1979; DieterlenLievre, 1975; Lassila et al., 1978; Lassila et al., 1982; Martin et al., 1978). Some reports suggested that the yolk sac remains as the major niche for definitive erythropoiesis until E20 (Bruns and Ingram, 1973; Dantschakoff, 1908). A recent histological and EM study suggested this process lasts until E19 (Niimi et al., 2008). In our analysis using molecular markers, prominent erythropoiesis in the yolk sac continues at least until E10 (Fig. 3 D-F), which wanes significantly by E15 (Nagai and Sheng, 2008). Combining these data, it is likely that some time between E12 and $E 15$, the bone marrow takes over as the major erythropoietic organ, although the yolk sac continues to contribute to this process until hatching (Fig. 4).

These studies, although showing that the yolk sac remains a major niche even for late definitive erythropoiesis,
Fig. 4. A timeline of primitive and definitive erythropoiesis in the chick embryo. Key events of erythropoiesis and some of developmental landmarks are listed, with primitive line-related events marked by circles and definitive linerelated events by squares. 
did not address the source of erythropoietic cells at late stages. Similar to the situation in early definitive erythropoiesis, the source of cells for later embryonic and post-hatching erythropoiesis remains contested. Erythropoietic cells in the bone marrow are seeded exogenously. Hematopoietic stem/progenitor cells that do not undergoing erythropoiesis, derived from both the dorsal aorta intraembryonically and the yolk sac extraembryonically, are in circulation at least from late E4 (Mclntyre et al., 2008; Nagai and Sheng, 2008). It is unclear whether they remain as dormant stem/ progenitor cells in circulation or in a transitory niche before the bone marrow niche starts to form at about E9 and becomes receptive for seeding by circulatory stem cells at about E12 (Bruns and Ingram, 1973; Dantschakoff, 1909; Metcalf and Moore, 1971; Romanoff, 1960).

Other intraembryonic erythropoietic organs, including the liver and spleen, make relatively minor contributions to definitive erythropoiesis during embryonic development. The liver, a major erythropoietic organ in mammalian embryos, is not considered to contribute significantly to definitive erythrocyte generation in chickens. It is noteworthy that development of chicken embryonic liver coincides with the initiation of yolk sac erythropoiesis. Large bilateral yolk sac veins, also known as omphalomesenteric veins or vitelline veins, merge as ductus venosus before reaching the sinus venosus part of the heart. Hepatic vessels are derived from out-branching of ductus venosus endothelium. At E3.5, a very small percentage of extraembryonic blood entering the heart goes through the liver. By E7, however, all yolk sac-derived blood needs to pass through liver tissue as the ductus venosus breaks down after hepatic vessel maturation. Indeed, erythropoietic cells are detected in the liver at E7 both intravascularly and extravascularly (Haff, 1914; Karrer, 1961; Romanoff, 1960; Wong and Cavey, 1993). Erythropoiesis in the liver, however, never becomes very active and stops by the end of E9 (Haff, 1914; Romanoff, 1960). Similarly, the spleen serves as a minor erythropoietic organ for a few days during mid-incubation period (Romanoff, 1960; Yassine et al., 1989). The relatively minor role of liver and spleen as embryonic erythropoietic organs in chickens, however, may not be a general phenomenon in birds, as in passerine birds, such as starling, these two organs were reported to participate in erythropoiesis throughout embryogenesis and for a few weeks after hatching (Romanoff, 1960).

A strong argument for yolk sac origin of hematopoietic cells seeding the bone marrow came from parabiosed and twinned chick embryos of opposite sex (Metcalf and Moore, 1971; Moore and Owen, 1965; Moore and Owen, 1967), in which approximately one fourth to a half of hematopoietic cells in the bone marrow at late embryonic stages are reciprocally derived from opposite sexes. This hypothesis was supported by experiments in which yolk sac-derived cells were injected into irradiated chick embryos, showing that yolk sac cells are capable of contributing to post-hatching bone marrow hematopoietic cell population (Lassila et al., 1978; Metcalf and Moore, 1971; Moore and Owen, 1967). Interpretation of these experiments, however, has to take into consideration the techniques used. For instance, scoring of mitosis at metaphase is not necessarily indicative of hematopoietic cell fate. More importantly, the timing of parabiosis (ranging from E4 to E8) would not distinguish yolk sac-generated from intraembryonically-generated hematopoietic cells in circulation. The age of yolk sac donor (E7) for irradiated embryos may include intraembryonically-generated hematopoietic cells either in circulation or temporarily taking up the yolk sac niche. Studies using chick/quail (Beaupain et al., 1979; Dieterlen-Lievre, 1975; Dieterlen-Lievre, 2005; Martin etal., 1978) and chick/chick (Lassila et al., 1978; Lassila et al., 1982) chimeras presented an opposite picture. Quail or chick embryos ranging from $\mathrm{HH} 9$ to $\mathrm{HH} 16$ were grafted to chick yolk sacs, and relative contributions of graft and host cells to circulating blood or bone marrow were analyzed. Increasing percentage of donor (embryonic) cells was detected in circulation as chimeras developed and after E17 made up the majority of cells in the bone marrow. These experiments overcame some of the problems in parabiotic/twin analyses, but were also limited by the relatively small sample number, reliability in identifying donor/host cells as hematopoietic cells and variations in the age and graft size of donor embryos, all of which could influence the interpretation. Nevertheless, the latter set of observations suggested that intraembryonically-derived hematopoietic cells make an increasingly significant, and possibly exclusive, contribution to the late embryonic and post-hatching definitive erythrocyte population. It is still unclear, however, whether hematopoietic cells detected in the dorsal aorta during early embryogenesis represent the hematopoietic stem cells seeded in the bone marrow.

An additional possible source of definitive hematopoietic stem cells, which so far has not received careful investigation, is the blood islands around regressed primitive streak near the tail bud. As discussed earlier, the distinction between embryonic and extraembryonic tissues is not clear-cut, especially in the posterior part of the developing embryo. New blood islands are continuously being formed in this area even at E3 when circulation has been well established. Whether to consider these blood islands as embryonic or extraembryonic may be a semantic issue. Molecularly, however, these blood islands can be distinguished from those generated earlier and located more peripherally (unpublished data) (Minko et al., 2003). It will be interesting to test whether these hematopoietic cells may have different differentiation potentials from more conventionally-defined and yolk saclocated hematopoietic cells.

\section{Conclusion}

The chick embryo has been and remains to be a superb model system for studying developmental hematopoiesis. It has played important historical roles in providing descriptions and conceptual frameworks fundamental to the field. With diverse model systems and rich resources of molecular and genomic information, elucidation of many currently unresolved questions concerning vertebrate hematopoietic development can be anticipated in the near future. The chick model can continue to make important contributions to this endeavor.

\section{Acknowledgements \\ I would like to thank Ms. Kanako Ota and RIKEN CDB library staff for help in obtaining articles not accessible electronically.}

\section{References}

ADAMSTONE, F.B. (1948). Experiments on the development of the amnion in the chick. JMorpho/83: 359-371. 
ADELMANN, H.B. (1966). The area vasculosa. In Marcello Malpighi and the evolution of embryology, vol. III. Cornell University Press, Ithaca, pp.11041153.

ALEV, C., MCINTYRE, B.A., NAGAI, H., SHIN, M., SHINMYOZU, K., JAKT, L.M. and SHENG, G. (2008). BetaA, the major beta globin in definitive red blood cells, is present from the onset of primitive erythropoiesis in chicken. Dev Dyn 237: 1193-1197.

ALEV, C., MCINTYRE, B.A., OTA, K. and SHENG, G. (2010). Dynamic expression of Endoglin, a TGF-beta co-receptor, during pre-circulation vascular development in chick. Int J Dev Bio/54: 737-742.

ALEV, C., SHINMYOZU, K., MCINTYRE, B.A. and SHENG, G. (2009). Genomic organization of zebra finch alpha and beta globin genes and their expression in primitive and definitive blood in comparison with globins in chicken. Dev Genes Evo/219: 353-360.

BAUMANN, R. and MEUER, H.J. (1992). Blood oxygen transport in the early avian embryo. Physiol Rev 72: 941-965.

BAUMANN, R., PADEKEN, S., HALLER, E.A. and BRILMAYER, T. (1983). Effects of hypoxia on oxygen affinity, hemoglobin pattern, and blood volume of early chicken embryos. Am J Physio/244: R733-741.

BEAUPAIN, D., MARTIN, C. and DIETERLEN-LIEVRE, F. (1979). Are developmental hemoglobin changes related to the origin of stem cells and site of erythropoiesis? Blood 53: 212-225

BELLAIRS, R. (1958). The conversion of yolk into cytoplasm in the chick blastoderm as shown by electron microscopy. J Embryol Exp Morpho/6: 129-161.

BELLAIRS, R. (1963). Differentiation of the yolk sac of the chick studied by electron microscopy. J Embryol Exp Morphol11: 201-225.

BELLAIRS, R. (1964). Biological aspects of the yolk of the hen's egg. Adv Morphog 4: $217-272$

BELLAIRS, R., BROMHAM, D.R. and WYLIE, C.C. (1967). The influence of the area opaca on the development of the young chick embryo. $J$ Embryol Exp Morphol17: 195-212.

BERTRAND, J.Y., CHI, N.C., SANTOSO, B., TENG, S., STAINIER, D.Y. and TRAVER, D. (2010). Haematopoietic stem cells derive directly from aortic endothelium during development. Nature 464: 108-111.

BOISSET, J.C., VAN CAPPELLEN, W., ANDRIEU-SOLER, C., GALJART, N., DZIERZAK, E. and ROBIN, C. (2010). In vivo imaging of haematopoietic cells emerging from the mouse aortic endothelium. Nature 464: 116-120.

BOLLEROT, K., ROMERO, S., DUNON, D. and JAFFREDO, T. (2005). Core binding factor in the early avian embryo: cloning of Cbfbeta and combinatorial expression patterns with Runx1. Gene Expr Patterns 6: 29-39.

BROWN, J.L. and INGRAM, V.M. (1974). Structural studies on chick embryonic hemoglobins. J Biol Chem 249: 3960-3972.

BRUNS, G.A. and INGRAM, V.M. (1973). The erythroid cells and haemoglobins of the chick embryo. Philos Trans R Soc Lond B Biol Sci266: 225-305

CAMPBELL, G.L.M., WEINTRAUB, H., MAYALL, B.H. and HOLTZER, H. (1971). Primitive erythropoiesis in early chick embryogenesis. II. Correlation between hemoglobin synthesis and the mitotic history. J Cel/ Bio/50: 669-681.

CHOI, K., KENNEDY, M., KAZAROV, A., PAPADIMITRIOU, J.C. and KELLER, G. (1998). A common precursor for hematopoietic and endothelial cells. Development 125: 725-732.

COOPER, S.J., WHEELER, D., DE LEO, A., CHENG, J.F., HOLLAND, R.A., MARSHALL GRAVES, J.A. and HOPE, R.M. (2006). The mammalian alphaDglobin gene lineage and a new model for the molecular evolution of alpha-globin gene clusters at the stem of the mammalian radiation. Mol Phylogenet Evo/38: 439-448.

DANTSCHAKOFF, V. (1908). Untersuchungen über die Entwickelung des Blutes und Bindegewebes bei den Vögeln. Anatomische Hefte 37: 471-587.

DANTSCHAKOFF, V. (1909). Uber die Entwicklung des knochenmarks bei den Vogeln und uber dessen Veranderungen bei Blutentziehungen und Ernahrungsstorungen. Arch. f. mikr. Anat. 74: 855-926.

DANTSCHAKOFF, V. (1909). Untersuchungen uber die Entwickelung von Blut und Bindegewebe bei Vogeln. Das lockere Bindegewebe des Huhnchens in Fetalen Leben. Arch. f. mikr. Anat. 73: 117-181.

DARDICK, I. and SETTERFIELD, G. (1978). Early origins of definitive erythroid cells in the chick embryo. Tissue Cel/10: 355-364.
DAVISON, F., KASPERS, B. and SCHAT, K.A. (2008). Avian Immunology. Academic Press.

DAWSON, A.B. (1936). Some observations on the primitive and definitive erythrocytes of the developing chick. Z Zellforsch Mikrosk Anat 24: 256-268.

DEFOUW, D.O., RIZZO, V.J., STEINFELD, R. and FEINBERG, R.N. (1989). Mapping of the microcirculation in the chick chorioallantoic membrane during normal angiogenesis. Microvasc Res 38: 136-147.

DIETERLEN-LIEVRE, F. (1975). On the origin of haemopoietic stem cells in the avian embryo: an experimental approach. J Embryol Exp Morpho/33: 607-619.

DIETERLEN-LIEVRE, F. (2005). Commitment of hematopoietic stem cells in avian and mammalian embryos: an ongoing story. Int J Dev Bio/49: 125-130.

DIETERLEN-LIEVRE, F., BEAUPAIN, D. and MARTIN, C. (1976). Origin of erythropoietic stem cells in avian development: shift from the yolk sac to an intraembryonic site. Ann Immunol (Paris) 127: 857-863.

DIETERLEN-LIEVRE, F. and LE DOUARIN, N.M. (2004). From the hemangioblast to self-tolerance: a series of innovations gained from studies on the avian embryo. Mech Dev 121: 1117-1128.

DIETERLEN-LIEVRE, F. and MARTIN, C. (1981). Diffuse intraembryonic hemopoiesis in normal and chimeric avian development. Dev Bio/88: 180-191.

DODGSON, J.B. and ENGEL, J.D. (1983). The nucleotide sequence of the adult chicken alpha-globin genes. J Biol Chem 258: 4623-4629.

DODGSON, J.B., MCCUNE, K.C., RUSLING, D.J., KRUST, A. and ENGEL, J.D. (1981). Adult chicken alpha-globin genes alpha $A$ and alpha $D:$ no anemic shock alpha-globin exists in domestic chickens. Proc Natl Acad Sci USA 78: 59986002.

DODGSON, J.B., STADT, S.J., CHOI, O.R., DOLAN, M., FISCHER, H.D. and ENGEL, J.D. (1983). The nucleotide sequence of the embryonic chicken betatype globin genes. J Biol Chem 258: 12685-12692.

DODGSON, J.B., STROMMER, J. and ENGEL, J.D. (1979). Isolation of the chicken beta-globin gene and a linked embryonic beta-like globin gene from a chicken DNA recombinant library. Cel/17: 879-887.

DOLAN, M., DODGSON, J.B. and ENGEL, J.D. (1983). Analysis of the adult chicken beta-globin gene. Nucleotide sequence of the locus, microheterogeneity at the 5 '-end of beta-globin mRNA, and aberrant nuclear RNA species. J Biol Chem 258: 3983-3990.

DOLAN, M., SUGARMAN, B.J., DODGSON, J.B. and ENGEL, J.D. (1981). Chromosomal arrangement of the chicken beta-type globin genes. Cel/24: 669-677.

DRAKE, C.J. (2003). Embryonic and adult vasculogenesis. Birth Defects Res C Embryo Today 69: 73-82.

DRAKE, C.J., HUNGERFORD, J.E. and LITTLE, C.D. (1998). Morphogenesis of the first blood vessels. Ann NY Acad Sci857: 155-179

DRAKE, C.J., LARUE, A., FERRARA, N. and LITTLE, C.D. (2000). VEGF regulates cell behavior during vasculogenesis. Dev Bio/224: 178-188.

DZIERZAK, E. (2002). Hematopoietic stem cells and their precursors: developmental diversity and lineage relationships. Immunol Rev 187: 126-138.

EDMONDS, R.H. (1966). Electron microscopy of erythropoiesis in the avian yolk sac. Anat Rec 154: 785-805.

EICHMANN, A., YUAN, L., MOYON, D., LENOBLE, F., PARDANAUD, L. and BREANT, C. (2005). Vascular development: from precursor cells to branched arterial and venous networks. Int J Dev Bio/49: 259-267.

ENGEL, J.D. and DODGSON, J.B. (1980). Analysis of the closely linked adult chicken alpha-globin genes in recombinant DNAs. Proc Nat/ Acad Sci USA 77 2596-2600.

ENGEL, J.D., RUSLING, D.J., MCCUNE, K.C. and DODGSON, J.B. (1983) Unusual structure of the chicken embryonic alpha-globin gene, pi. Proc Nat/ Acad Sci USA 80: 1392-1396.

FORKNER, C.E. (1929). Blood and bone marrow cells of the domestic fowl. J Exp Med50: 121-141.

FRASER, R.C. (1961). Hemoglobin formation in the chick embryo. Exp Cel/Res 25 418-427.

GEERTS, W.J., LAMERS, W.H. and MOORMAN, A.F. (1993). Differences in erythropoiesis in normal chicken and quail embryos. Histochem J25: 280-290.

GOH, S.H., LEE, Y.T., BHANU, N.V., CAM, M.C., DESPER, R., MARTIN, B.M., MOHARRAM, R., GHERMAN, R.B. and MILLER, J.L. (2005). A newly discov- 


\section{G. Sheng}

ered human alpha-globin gene. Blood106: 1466-1472.

GONZALEZ-CRUSSI, F. (1971). Vasculogenesis in the chick embryo. An ultrastructural study. Am J Anat 130: 441-460.

GRAF, T. (2002). Differentiation plasticity of hematopoietic cells. Blood99: 30893101.

HAFF, R. (1914). Bindegewebe- und blutbildungs-progesse in der embryonalen leber des huhns. arch. mikrosk. Anat. EntwMech. 84: 321-350.

HAGOPIAN, H.K. and INGRAM, V.M. (1971). Developmental changes of erythropoiesis in cultured chick blastoderms. J Cel/ Bio/51: 440-451.

HAMBURGER, V. and HAMILTON, H.L. (1992). A series of normal stages in the development of the chick embryo. 1951. Dev Dyn 195: 231-272.

HASHIMOTO, K. and WILT, F.H. (1966). The heterogeneity of chicken hemoglobin. Proc Natl Acad Sci USA 56: 1477-1483.

HUBER, T.L., KOUSKOFF, V., FEHLING, H.J., PALIS, J. and KELLER, G. (2004). Haemangioblast commitment is initiated in the primitive streak of the mouse embryo. Nature 432: 625-630.

INGRAM, V.M. (1956). A specific chemical difference between the globins of normal human and sickle-cell anaemia haemoglobin. Nature 178: 792-794.

INTERNATIONAL CHICKEN GENOME SEQUENCING CONSORTIUM. (2004). Sequence and comparative analysis of the chicken genome provide unique perspectives on vertebrate evolution. Nature 432: 695-716.

JAFFREDO, T., ALAIS, S., BOLLEROT, K., DREVON, C., GAUTIER, R., GUEZGUEZ, B., MINKO, K., VIGNERON, P. and DUNON, D. (2003). Avian HSC emergence, migration, and commitment toward the T cell lineage. FEMS Immunol Med Microbio/39: 205-212.

JAFFREDO, T., BOLLEROT, K., SUGIYAMA, D., GAUTIER, R. and DREVON, C. (2005). Tracing the hemangioblast during embryogenesis: developmental relationships between endothelial and hematopoietic cells. Int J Dev Bio/49: 269277.

JAFFREDO, T., GAUTIER, R., BRAJEUL, V. and DIETERLEN-LIEVRE, F. (2000). Tracing the progeny of the aortic hemangioblast in the avian embryo. Dev Biol 224: 204-214.

JAFFREDO, T., GAUTIER, R., EICHMANN, A and DIETERLEN-LIEVRE, $F$. (1998). Intraaortic hemopoietic cells are derived from endothelial cells during ontogeny. Development 125: 4575-4583.

JORDAN, H.E. (1916). Evidence of hemogenic capacity of endothelium. Anat Rec 10: $417-420$.

KARRER, H.E. (1961). Electron microscope observations on chick embryo liver. Glycogen, bile canaliculi, inclusion bodies and hematopoiesis. JUltrastruct Res 5: $116-141$

KESSEL, J. and FABIAN, B.C. (1985). Graded morphogenetic patterns during the development of the extraembryonic blood system and coelom of the chick blastoderm: a scanning electron microscope and light microscope study. $\mathrm{Am} J$ Anat 173: 99-112.

KINGSLEY, P.D., MALIK, J., EMERSON, R.L., BUSHNELL, T.P., MCGRATH, K.E., BLOEDORN, L.A., BULGER, M. and PALIS, J. (2006). «Maturational» globin switching in primary primitive erythroid cells. Blood 107: 1665-1672.

KISSA, K. and HERBOMEL, P. (2010). Blood stem cells emerge from aortic endothelium by a novel type of cell transition. Nature 464: 112-115.

LASSILA, O., ESKOLA, J., TOIVANEN, P., MARTIN, C. and DIETERLEN-LIEVRE, F. (1978). The origin of lymphoid stem cells studied in chick yold sac-embryo chimaeras. Nature 272: 353-354.

LASSILA, O., MARTIN, C., TOIVANEN, P. and DIETERLEN-LIEVRE, F. (1982). Erythropoiesis and lymphopoiesis in the chick yolk-sac-embryo chimeras: contribution of yolk sac and intraembryonic stem cells. Blood59: 377-381.

LE DOUARIN, N.M. (1978). Ontogeny of hematopoietic organs studied in avian embryo interspecific chimeras. In Differentiation of Normal and Neoplastic Hematopoietic Cells. Cold Spring Harbor Press, New York, pp.5-31.

LE NOBLE, F., MOYON, D., PARDANAUD, L., YUAN, L., DJONOV, V., MATTHIJSEN, R., BREANT, C., FLEURY, V. and EICHMANN, A. (2004). Flow regulates arterial-venous differentiation in the chick embryo yolk sac. Development 131: 361-375.

LEESON, T.S. and LEESON, C.R. (1963). The Chorio-Allantois Of The Chick. Light And Electron Microscopic Observations At Various Times Of Incubation. J Anat 97: 585-595.
LEMEZ, L. (1964). The Blood Of Chick Embryos: Quantitative Embryology At A Cellular Level. Adv Morphog 4: 197-245.

LILLIE, F.R. (1919). The development of the chick; an introduction to embryology. H. Holt and Company, New York.

LUCAS, A.M. and JAMROZ, C. (1961). Atlas of avian hematology. U.S. Dept. of Agriculture, Washington, D.C.

MANWELL, C., BAKER, C.M. and BETZ, T.W. (1966). Ontogeny of haemoglobin in the chicken. J Embryol Exp Morphol 16: 65-81.

MANWELL, C., BAKER, C.M., ROSLANSKY, J.D. and FOGHT, M. (1963). Molecular Genetics Of Avian Proteins, li. Control Genes And Structural Genes For Embryonic And Adult Hemoglobins. Proc Nat/ Acad Sci USA 49: 496-503.

MARTIN, C., BEAUPAIN, D. and DIETERLEN-LIEVRE, F. (1978). Developmenta relationships between vitelline and intra-embryonic haemopoiesis studied in avian 'yolk sac chimaeras'. Cel/ Differ 7: 115-130.

MASON, M.M., LEE, E., WESTPHAL, H. and REITMAN, M. (1995). Expression of the chicken beta-globin gene cluster in mice: correct developmental expression and distributed control. Mol Cel/ Biol 15: 407-414.

MCINTYRE, B.A., ALEV, C., TARUI, H., JAKT, L.M. and SHENG, G. (2008) Expression profiling of circulating non-red blood cells in embryonic blood. $B M C$ Dev Bio/8: 21

MCNAGNY, K.M. and GRAF, T. (2003). E26 leukemia virus converts primitive erythroid cells into cycling multilineage progenitors. Blood 101: 1103-1110.

MELKONIAN, G., MUNOZ, N., CHUNG, J., TONG, C., MARR, R. and TALBOT, P. (2002). Capillary plexus development in the day five to day six chick chorioallantoic membrane is inhibited by cytochalasin D and suramin. J Exp Zoo/292: 241-254.

METCALF, D. and MOORE, M.A.S. (1971). Haemopoietic cells. North-Holland Pub. Co., Amsterdam

MINIE, M., CLARK, D., TRAINOR, C., EVANS, T., REITMAN, M., HANNON, R. GOULD, H. and FELSENFELD, G. (1992). Developmental regulation of globin gene expression. J Cell Sci Supp/16: 15-20.

MINKO, K., BOLLEROT, K., DREVON, C., HALLAIS, M.F. and JAFFREDO, T. (2003). From mesoderm to blood islands: patterns of key molecules during yolk sac erythropoiesis. Gene Expr Patterns 3: 261-272.

MOORE, M.A. and OWEN, J.J. (1965). Chromosome marker studies on the development of the haemopoietic system in the chick embryo. Nature 208: 956.

MOORE, M.A. and OWEN, J.J. (1967). Chromosome marker studies in the irradiated chick embryo. Nature 215: 1081-1082.

MOORE, M.A. and OWEN, J.J. (1967). Stem cell migration in developing myeloid and lymphoid systems. Lancet 2: 658-659.

MURPHY, M.E. and CARLSON, E.C. (1978). An ultrastructural study of developing extracellular matrix in vitelline blood vessels of the early chick embryo. $A m \mathrm{~J}$ Anat 151: 345-375.

MURRAY, P.D.F. (1932). The development in vitro of the blood of the early chick embryo. Proceedings of the Royal Society of London. Series B 111: 497-521.

NAGAI, H. and SHENG, G. (2008). Definitive erythropoiesis in chicken yolk sac. Dev Dyn 237: 3332-3341.

NAKAZAWA, F., NAGAI, H., SHIN, M. and SHENG, G. (2006). Negative regulation of primitive hematopoiesis by the FGF signaling pathway. Blood 108: 33353343.

NEW, D.A. (1959). The adhesive properties and expansion of the chick blastoderm. $J$ Embryol Exp Morpho/7: 146-164.

NIIMI, G., USUDA, N., SHINZATO, M., KANEKO, C., NAGAMURA, Y. and PEREDA, J. (2008). Histochemical study of the definitive erythropoietic foci in the chicken yolk sac. Ital J Anat Embryol 113: 9-16.

NOCOLET, G. (1970). Analyse autoradiographique de la localisation des differentes ebauches presomptives dans la ligne primitive de l'embryon de poulet. $J$ Embryol. Exp. Morph. 23: 79-108.

OLAH, I., MEDGYES, J. and GLICK, B. (1988). Origin of aortic cell clusters in the chicken embryo. Anat Rec 222: 60-68.

OPPENHEIM, R.W. (1966). Amniotic contraction and embryonic motility in the chick embryo. Science 152: 528-529.

ORKIN, S.H. and ZON, L.I. (2002). Hematopoiesis and stem cells: plasticity versus developmental heterogeneity. Nat Immuno/3: 323-328. 
PARDANAUD, L., LUTON, D., PRIGENT, M., BOURCHEIX, L.M., CATALA, M. and DIETERLEN-LIEVRE, F. (1996). Two distinct endothelial lineages in ontogeny, one of them related to hemopoiesis. Development 122: 1363-1371.

PARK, C., MA, Y.D. and CHOI, K. (2005). Evidence for the hemangioblast. Exp Hemato/33: 965-970.

PATEL, V.S., COOPER, S.J., DEAKIN, J.E., FULTON, B., GRAVES, T., WARREN W.C., WILSON, R.K. and GRAVES, J.A. (2008). Platypus globin genes and flanking loci suggest a new insertional model for beta-globin evolution in birds and mammals. BMC Bio/6: 34.

PEEBLES, F. (1898). Some experiments on the primtive streak of the chick. Wilhelm Roux Archiv 7: 405-429.

PIERCE, M.E. (1933). The amnion of the chick as a independent effector. J Expt/ Zoo/65: 443-473.

PRINDULL, G.A. and FIBACH, E. (2007). Are postnatal hemangioblasts generated by dedifferentiation from committed hematopoietic stem cells? Exp Hemato/35: 691-701.

PSYCHOYOS, D. and STERN, C.D. (1996). Fates and migratory routes of primitive streak cells in the chick embryo. Development 122: 1523-1534.

RAWLES, M.E. (1936). A study in the localization of organ-forming areas in the chick blastoderm of the head-process stage. J Exp Zoo/72: 271-315.

REITMAN, M., GRASSO, J.A., BLUMENTHAL, R. and LEWIT, P. (1993). Primary sequence, evolution, and repetitive elements of the Gallus gallus (chicken) beta-globin cluster. Genomics 18: 616-626.

ROMANOFF, A.L. (1960). The extraembryonic membranes. In The avian embryo. structural and functional development. The Macmillan Company, New York, pp.1041-1140.

ROMANOFF, A.L. (1960). The hematopoietic, vascular and lymphatic systems. In The avian embryo: structural and functional development. The Macmillan Company, New York, pp.568-678.

ROSENQUIST, G.C. (1966). A radioautographic study of labeled grafts in the chick blastoderm. 38: 71-110.

RUCKERT, J. (1906). Entwickelung der extraembryonalen Gefasse de Vogel. In Entwickelungslehre Der Wirbeltiere, vol. I part $1^{2}$-2 (ed. HERTWIG, O.). Verlag von Gustav Fischer, Jena, pp.1203-1244.

RUDNICK, D. (1938). Differentiation in culture of pieces of the early chick blastoderm. J Exp Zoo/79: 399-427.

SABIN, F.R. (1917). Preliminary note on the differentiation of angioblasts and the method by which they produce blood-vessels, blood-plasma and red blood-cells as seen in the living chick. Anatomical Record 13: 199-204.

SABIN, F.R. (1920). Studies on the origin of blood-vessels and of red bloodcorpuscles as seen in the living blastderm of chicks during the second day of incubation. Carnegie Inst. Wash. Publ. Contribs. Embryol. 9: 213-262.

SAHA, A. (1964). Comparative Studies On Chick Hemoglobins. Biochim Biophys Acta 93: 573-584.

SAHA, A. and GHOSH, J. (1965). Comparative studies on avian hemoglobins. Comp Biochem Physiol 15: 217-235.

SAWADA, K. and AOYAMA, H. (1999). Fate maps of the primitive streak in chick and quail embryo: ingression timing of progenitor cells of each rostro-caudal axial level of somites. Int J Dev Bio/43: 809-815.

SCHOENWOLF, G.C., GARCIA-MARTINEZ, V. and DIAS, M.S. (1992). Mesoderm movement and fate during avian gastrulation and neurulation. Dev Dyn 193: 235-248.

SHIMIZU, K. (1972). Ontogeny of chicken hemoglobin. I. Electrophoretic study of the heterogeneity of hemoglobin in development. Dev Growth Diff 14: 43-55.

SHIN, M., NAGAI, H. and SHENG, G. (2009). Notch mediates Wnt and BMP signals in the early separation of smooth muscle progenitors and blood/endothelial common progenitors. Development 136: 595-603.
SIATSKAS, C. and BOYD, R. (2000). Regulation of chicken haemopoiesis by cytokines. Dev Comp Immuno/24: 37-59.

SIMONS, J.A. (1966). The ontogeny of the multiple molecular forms of hemoglobin in the developing chick under normal and experimental conditions. J Exp Zool 162: $219-230$

SMALL, J.V. and DAVIES, H.G. (1972). Erythropoiesis in the yolk sac of the early chick embryo: an electron microscope and microspectrophotometric study. Tissue Cel/4: 341-378.

SPRATT, N.T., JR. (1942). Location of organ-specific regions and their relationship to the development of the primtiive streak in the early chick blastoderm. $J$ Exp Zoo/89: 69-101.

SPRATT, N.T., JR. (1946). Formation of the primitive streak in the explanted chick blastoderm marked with carbon particles. J Exp Zoo/103: 259-304.

SPRATT, N.T., JR. (1947). Regresssion and shortening of the primitive streak in the explanted chick blastoderm. J Exp Zoo/104: 68-100.

SPRATT, N.T., JR. and HAAS, H. (1965). Germ Layer Formation And The Role Of The Primitive Streak In The Chick. I. Basic Architecture And Morphogenetic Tissue Movements. J Exp Zoo/158: 9-38.

STEINMETZ, H. (1930). Die Embryonalenentwick- lung des Blasshuhns (Fulcia atra) unter besonderer Berucksichtigung der Allantois. Morphol. Jahrb. 64: 275 338.

SUGIYAMA, S. (1926). Origin of thrombocytes and of the different types of bloodcells as seen in the living chick blastoderm. Carnegie Inst. Wash. Publ. Contribs. Embryol. 18: 121-147.

UENO, H. and WEISSMAN, I.L. (2006). Clonal analysis of mouse development reveals a polyclonal origin for yolk sac blood islands. Dev Cel/11: 519-533.

VAN DER HELM, H.J. and HUISMAN, T.H.J. (1958). The two hemoglobin components of the chicken. Science 127: 762-763.

VAN MIEROP, L.H. and BERTUCH, C.J., JR. (1967). Development of arterial blood pressure in the chick embryo. Am J Physio/212: 43-48.

VILLEPONTEAU, B., LANDES, G.M., PANKRATZ, M.J. and MARTINSON, H.G. (1982). The chicken beta globin gene region. Delineation of transcription units and developmental regulation of interspersed DNA repeats. J Biol Chem 257: 11015-11023.

VILLEPONTEAU, B. and MARTINSON, H. (1981). Isolation and characterization of the complete chicken beta-globin gene region: frequent deletion of the adult beta-globin genes in lambda. Nucleic Acids Res 9: 3731-3746.

VOGELI, K.M., JIN, S.W., MARTIN, G.R. and STAINIER, D.Y. (2006). A common progenitor for haematopoietic and endothelial lineages in the zebrafish gastrula. Nature 443: 337-339.

WEINTRAUB, H., CAMPBELL, G.L.M. and HOLTZER, H. (1971). Primitive erythropoiesis in early chick embryogenesis. I. Cell cycle kinetics and the control of cell division. J Cel/ Bio/50: 652-668.

WENG, W., SUKOWATI, E.W. and SHENG, G. (2007). On hemangioblasts in chicken. PLOS ONE2: e1228.

WILT, F.H. (1962). The ontogeny of chick embryo hemoglobin. Proc Nat/ Acad Sci USA 48: 1582-1590.

WILT, F.H. (1967). The control of embryonic hemoglobin synthesis. Adv Morphog 6: 89-125.

WONG, G.K. and CAVEY, M.J. (1993). Development of the liver in the chicken embryo. II. Erythropoietic and granulopoietic cells. Anat Rec 235: 131-143.

WU, K.C., STREICHER, J., LEE, M.L., HALL, B.K. and MULLER, G.B. (2001). Role of motility in embryonic development I: Embryo movements and amnion contractions in the chick and the influence of illumination. JExp Zoo/291: 186194.

YASSINE, F., FEDECKA-BRUNER, B. and DIETERLEN-LIEVRE, F. (1989). Ontogeny of the chick embryo spleen-a cytological study. Cel/ Differ Dev27: 2945 . 


\section{Further Related Reading, published previously in the Int. J. Dev. Biol.}

See our recent Special Issue Placenta edited by Joan S. Hunt and Kent L. Thornburg at: http://www.ijdb.ehu.es/web/contents.php?vol=54\&issue=2-3

Dynamic expression of Endoglin, a TGF-beta co-receptor, during pre-circulation vascular development in chick Cantas Alev, Brendan A.S. Mclntyre, Kanako Ota and Guojun Sheng

Int. J. Dev. Biol. (2010) 54: 737-742

Tracing the hemangioblast during embryogenesis: developmental relationships between endothelial and hematopoietic cells Thierry Jaffredo, Karine Bollerot, Daisuke Sugiyama, Rodolphe Gautier and Cécile Drevon Int. J. Dev. Biol. (2005) 49: 269-277

Vascular development: from precursor cells to branched arterial and venous networks Anne Eichmann, Li Yuan, Delphine Moyon, Ferdinand leNoble, Luc Pardanaud and Christiane Bréant Int. J. Dev. Biol. (2005) 49: 259-267

Commitment of hematopoietic stem cells in avian and mammalian embryos: an ongoing story Françoise Dieterlen-Lièvre Int. J. Dev. Biol. (2005) 49: 125-130


5 yr ISI Impact Factor $(2009)=3.253$

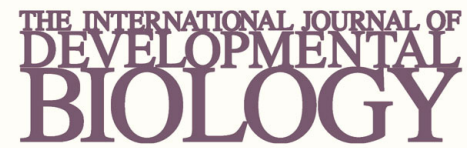

Volume 54 Nos. 6/7 Special Issue
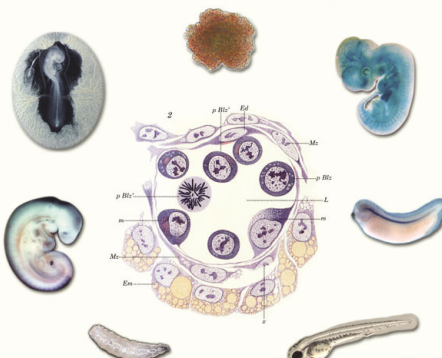

Developmental Hematopoiesis

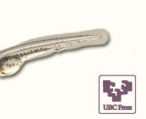

